\title{
New data on the western Balkan leuciscids Alburnoides and Alburnus (Teleostei, Leuciscidae) from the Vjosa River, Albania
}

\author{
Nina G. Bogutskaya', Harald Ahnelt ${ }^{1,2}$ \\ I First Zoological Department, Natural History Museum in Vienna, Burging 7, 1010 Vienna, Austria \\ 2 Department of Theoretical Biology, University of Vienna, Althanstrasse 14, 1090 Vienna, Austria \\ Corresponding author: Nina G. Bogutskaya (nina.bogutskaya@nhm-wien.ac.at) \\ Academic editor: M. Elina Bichuette | Received 15 May 2019 | Accepted 18 July 2019 | Published 7 August 2019 \\ http://zoobank.org/A4379130-4E1D-4A84-B6A3-0EAF3B564C57 \\ Citation: Bogutskaya NG, Ahnelt H (2019) New data on the western Balkan leuciscids Alburnoides and \\ Alburnus (Teleostei, Leuciscidae) from the Vjosa River, Albania. ZooKeys 870: 101-115. https://doi.org/10.3897/ \\ zookeys. 870.36235
}

\begin{abstract}
The first voucher-confirmed record of Alburnus scoranza and the first morphological description of Alburnoides for the Vjosa River system in Albania are reported with a brief discussion of the diagnostic morphological traits and taxonomic assignment of both species.
\end{abstract}

\section{Keywords}

Biodiversity, freshwater fish, range extension, southeastern Adriatic ecoregion

\section{Introduction}

The Vjosa River (Aoos in Greece) belongs to the South Adriatic-Ionian zoogeographical division of Economidis and Bănărescu (1991) and is the southernmost river drainage of the Southeastern Adriatic ecoregion of Zogaris and Economou (2017). It originates in western Greece, flows through Albania, and drains into the southern Adriatic Sea. Some genera of the Greek (e.g., Economidis 1989, Durand et al. 1999, Economou et al. 2007, Geiger et al. 2014, Barbieri et al. 2017, Koutsikos et al. 2019) and the Albanian sections of the Vjosa/Aoos River (e.g., Šanda et al. 2008, Marková et al. 2010, Stierandová et al. 2016) were investigated mostly within wider phylogenetic studies, and summarising lists of fish species in the Albanian section have been also published 
(Ahnelt and Elvira 1991, Rakaj and Flloko 1995, Shumka et al. 2010, Graf et al. 2017, Meulenbroek et al. 2018, Shumka et al. 2018a,b, Weiss et al. 2018). However, any new data on morphology and distribution of the Vjosa fishes could help for further research, especially in taxonomically difficult groups or species complexes.

Herein, we report the first voucher-confirmed records of Alburnoides based on a historical sample and the Scoranza bleak Alburnus scoranza Bonaparte, 1845 present in the middle and lower part of the Vjosa River drainage in Albania; we also present first morphological data for the Albanian Vjosa populations of these two cyprinids. Their species-level identifications are discussed based on some morphological comparisons.

\section{Materials and methods}

The Natural History Museum in Vienna (NMW) houses two small collections of freshwater fishes from the lower and middle course of the Vjosa River, from Selenica and Tepelena, respectively. These fishes were sampled in 1894 at the lower course of the Vjosa River near the town of Selenica (Selenicë) (Ahnelt and Elvira 1991) and in 1914 in the Bença River, a tributary of the Vjosa, near the village of Bença. No ecological data were available for either collection.

For methods and terminology of measurements and counts, and the comparative material, see Bogutskaya et al. (2010).

\section{Results}

\section{Taxonomy}

Alburnoides cf. devolli (a member of the Alburnoides prespensis complex of Stierandová et al. (2016)

Fig. 1

New record. NMW 55706, 40 specimens, SL 36.5-52.8 mm (mean $45.0 \mathrm{~mm}$ ); Albania: Vjosa River drainage, Bença River at Bença village, ca. $6 \mathrm{~km}$ upstream of confluence with $\mathrm{tVjosa}\left(\mathrm{ca} .40^{\circ} 18^{\prime} 22^{\prime \prime} \mathrm{N}, 20^{\circ} 1^{\prime} 29^{\prime \prime} \mathrm{E}\right)$, collector(s) unknown, collected in July 1914, donated to NMW by F. Steindachner.

Identification. Based on 40 specimens except for numbers of pharyngeal teeth and measurements as specified below. Dorsal-fin branched rays $81 / 2$; anal-fin branched rays $101 / 2-12^{1 / 2}$ (mode $11 \frac{1}{2}$, mean $11.31 \frac{1}{2}$ ); scales in lateral series $45-51$ (mean 48.1); total lateral-line scales 43-50 (mean 46.8); later-line scales to posterior margin of hypurals 43-49 (mean 45.8); ventral keel $(\mathrm{n}=20)$ from completely to $1 / 3$ scaled, commonly $3 / 4$ scaled; mouth with a fleshy snout protruding lower jaw; gill-rakers 7-9 (mode 8, mean 8); total vertebrae 39-41 (mode 40, mean 40.4) with abdominal vertebrae 20-21 (mode 20, mean 20.5), predorsal abdominal 13-15 (mode 14, mean 13.70) and caudal vertebrae 19-21 

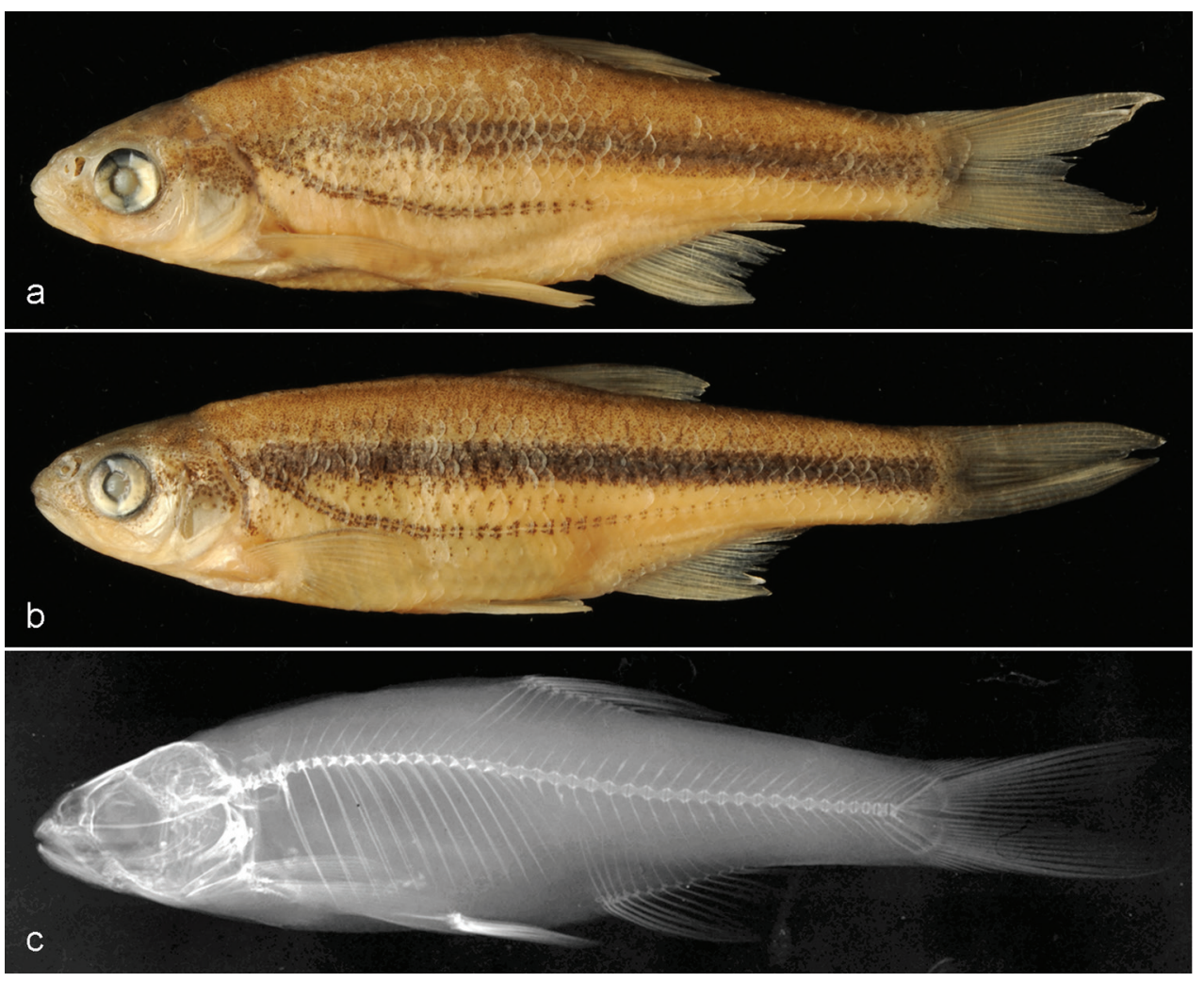

Figure I. Alburnoides cf. devolli (member of A. prespensis complex of Stierandová et al. (2016), NMW 55706. External appearance of a male SL $50.5 \mathrm{~mm}$ and $\mathbf{b}$ female $47.9 \mathrm{~mm}$, and $\mathbf{c}$ radiograph of same specimen as $\mathbf{a}$.

Table I. Morphometric data of Alburnoides cf. devolli (member of Alburnoides prespensis complex of Stierandová et al. (2016) from river Bença (Vjosa drainage, Albania) deposited at NMW.

\begin{tabular}{l|c|c|c|c}
\hline \multicolumn{1}{|c|}{ Alburnoides cf. devolli } & NMW 55706: 1 & $\mathbf{5 5 7 0 6 : ~ 2}$ & $\mathbf{5 5 7 0 6 : ~ 3}$ & $\mathbf{5 5 7 0 6 : 4}$ \\
\hline Standard length (mm) & 50.5 & 51.7 & 52.2 & 52.8 \\
\hline Percent of standard length & \multicolumn{4}{l}{} \\
\hline Body depth at dorsal-fin origin & 28.5 & 30.1 & 29.8 & 29.9 \\
\hline Body width at dorsal-fin origin & 10.9 & 13.7 & 11.9 & 13.0 \\
\hline Predorsal length & 54.6 & 55.7 & 57.2 & 56.4 \\
\hline Postdorsal length & 37.9 & 36.3 & 35.8 & 37.5 \\
\hline Prepelvic length & 49.5 & 50.7 & 50.9 & 48.7 \\
\hline Preanal length & 66.9 & 68.7 & 69.3 & 65.2 \\
\hline Pectoral - pelvic-fin origin length & 23.6 & 24.1 & 25.4 & 24.0 \\
\hline Pelvic- anal-fin origin length & 19.0 & 18.3 & 15.4 & 17.3 \\
\hline Caudal peduncle length & 23.9 & 21.8 & 22.9 & 24.3 \\
\hline Caudal peduncle depth & 12.3 & 13.2 & 12.6 & 12.3 \\
\hline Caudal peduncle width & 8.9 & 9.0 & 9.1 & 8.9 \\
\hline Dorsal-fin base length & 11.6 & 12.3 & 11.4 & 11.7 \\
\hline Dorsal-fin depth & 22.5 & 20.7 & 21.3 & 20.9 \\
\hline Anal-fin base length & 13.6 & 14.5 & 14.6 & 13.3 \\
\hline Anal-fin depth & 18.6 & 16.8 & 15.3 & 17.1 \\
\hline Pectoral fin length & 21.0 & 20.4 & 20.2 & 20.5 \\
\hline
\end{tabular}




\begin{tabular}{|c|c|c|c|c|}
\hline Alburnoides cf. devolli & NMW 55706: 1 & 55706: 2 & 55706: 3 & 55706: 4 \\
\hline Head length & 26.4 & 26.5 & 25.6 & 24.9 \\
\hline Head depth at nape & 18.8 & 19.2 & 18.2 & 18.8 \\
\hline Head width (maximum) & 12.7 & 12.6 & 12.4 & 12.7 \\
\hline Snout length & 7.6 & 7.4 & 7.5 & 7.5 \\
\hline Eye diameter (horizontal) & 7.6 & 7.2 & 6.8 & 7.6 \\
\hline Postorbital distance & 13.0 & 12.7 & 13.1 & 12.2 \\
\hline Interorbital width & 8.8 & 8.3 & 8.8 & 8.8 \\
\hline Length of upper jaw & 8.9 & 8.6 & 8.7 & 8.9 \\
\hline Length of lower jaw & 11.3 & 11.1 & 10.0 & 11.3 \\
\hline \multicolumn{5}{|l|}{ Percent of head length } \\
\hline Head depth at nape & 71.1 & 72.4 & 76.0 & 73.0 \\
\hline Head width (maximum) & 48.3 & 47.3 & 49.7 & 49.9 \\
\hline Snout length & 28.7 & 28.1 & 29.4 & 30.0 \\
\hline Eye diameter (horizontal) & 28.9 & 27.2 & 29.4 & 27.4 \\
\hline Postorbital distance & 49.6 & 45.8 & 50.9 & 51.2 \\
\hline Interorbital width & 33.5 & 31.3 & 33.6 & 35.2 \\
\hline Length of upper jaw & 33.8 & 32.5 & 35.0 & 35.1 \\
\hline Length of lower jaw & 42.7 & 41.9 & 43.2 & 40.3 \\
\hline Depth of operculum & 40.3 & 39.9 & 38.2 & 40.5 \\
\hline \multicolumn{5}{|l|}{ Percent of caudal peduncle length } \\
\hline Depth of caudal peduncle & 51.3 & 60.7 & 53.2 & 52.0 \\
\hline \multicolumn{5}{|l|}{ Percent of interorbital distance } \\
\hline Eye diameter (horizontal) & 86.1 & 86.9 & 87.3 & 77.8 \\
\hline
\end{tabular}

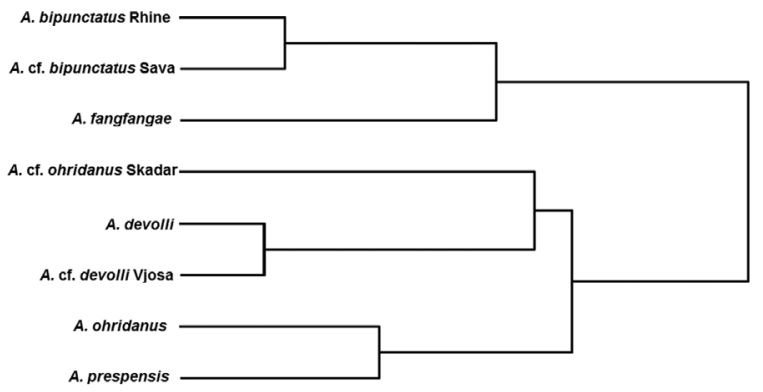

a

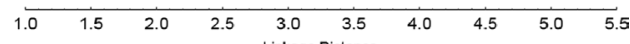

Linkage Distance

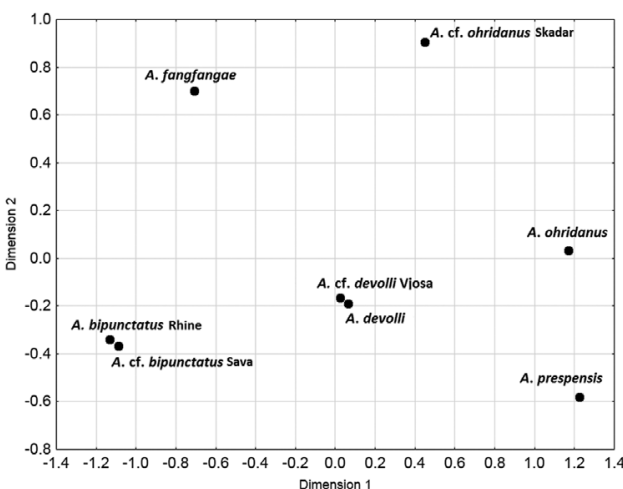

b Dimension 1

Figure 2. a Cluster analysis b multidimensional scaling results for Alburnoides samples of North, Black, and Adriatic basins from Rhine southwards to Vjosa in Albania based on data for counts and coded qualitative characters as in Table 3. Adriatic samples of Alburnoides prespensis complex named as presumed species. 


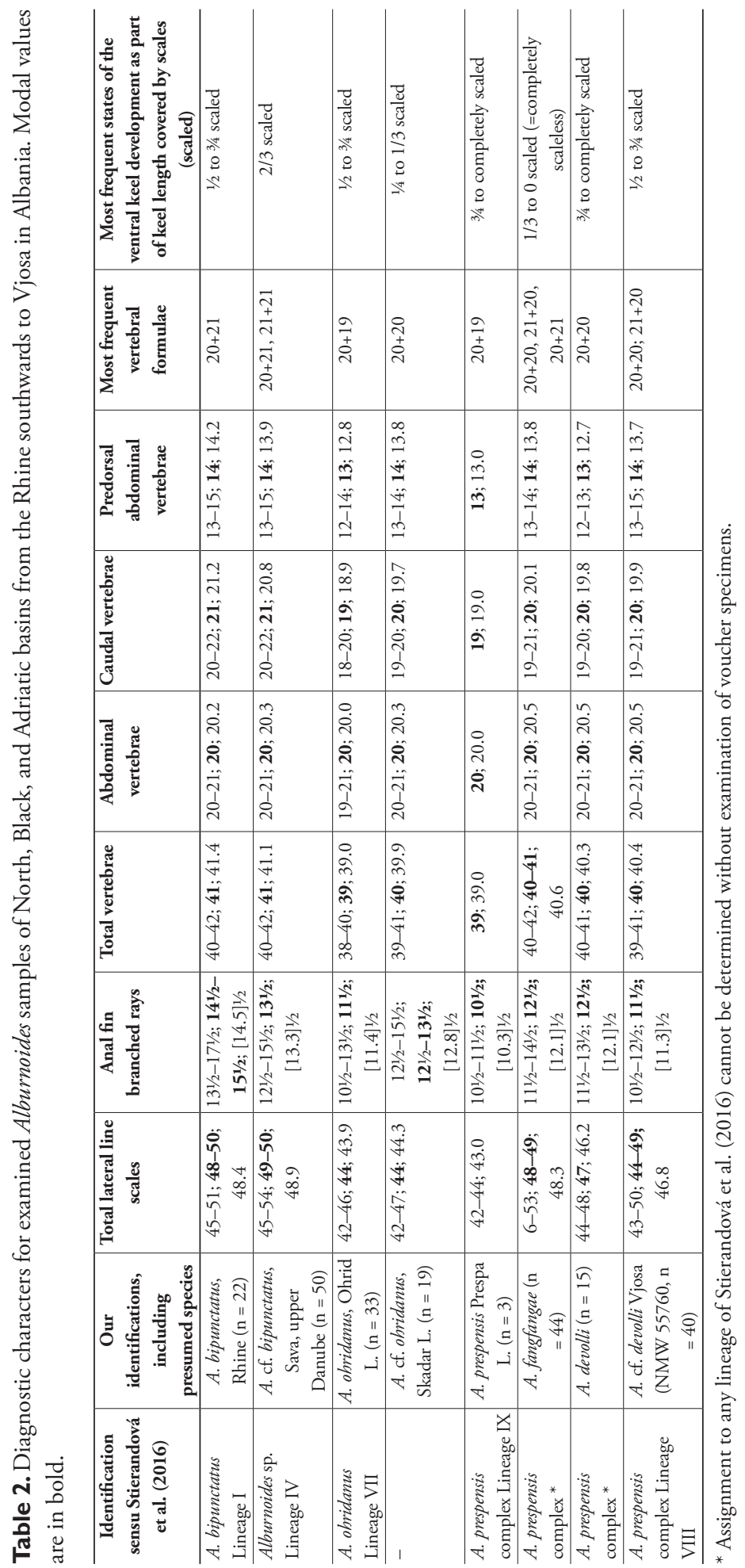


(mode 20, mean 19.9); most frequent vertebral formulae 20+20 and 21+20; pharyngeal teeth 2.5-4.2 ( $\mathrm{n}=5)$. Measurements for four specimens with SL over $50 \mathrm{~mm}$ see Table 1.

For a morphological comparison with close species (and presumptive species) see Table 2 and Fig. 2.

Identification of the sample as Alburnoides cf. devolli is based on statistical analyses (Fig. 2). See Discussion for the taxonomy of $A$. devolli Bogutskaya, Zupančič et Naseka, 2012.

Colouration (preserved). The body is pale fawn, the back darker than the ventral side. A distinct, black to dark grey stripe extends from the posterior margin of the orbit to the base of the caudal fin. The ventral side of the belly and of the tail is unpigmented. The lateral line is lined dorsally and ventrally by pigment along its entire length, most distinct in its anterior half to about below the origin of the dorsal fin. The fins are hyaline with tiny melanophores lining the dorsal and caudal fin rays, the anterior rays of the anal and the dorsal rays of the pectoral fins.

\section{Alburnus scoranza Bonaparte, 1845}

Fig. 3

New record. NMW 87654, 1 specimen, SL 70.8 mm; Albania: Vjosa River system: Selenica $\left(40^{\circ} 32^{\prime} \mathrm{N}, 19^{\circ} 38^{\prime} \mathrm{E}\right)$; collected by Pola Expedition, Franz Steindachner, 4 July 1894. - NMW 87658-87659, 3 specimens, SL 90.8-125.6 mm; same data as NMW 87654.

Identification. Measurements see Table 3. Dorsal-fin branched rays $81 / 2$; anal-fin branched rays $141 \frac{1}{2}$ ( 1 specimen) or $15 \frac{1}{2}$ (3 specimens); anal-fin origin behind base of $5^{\text {th }}(2), 6^{\text {th }}\left(1\right.$; Fig. 3c) or $7^{\text {th }}(1)$ branched dorsal-fin ray; mouth upturned, mouth cleft straight, tip of mouth about at level with upper margin of pupil; keel between pelvic fins and anus completely exposed, variably sharp; scales in lateral series 47-51 (mean 48.8); total lateral-line scales 45-51 (mean 48.3); later-line scales to posterior margin of hypurals 45-48 (mean 46.0); gill rakers 22-25 (23.5); total vertebrae $41(22+19$, 3 specimens) or $42(22+20,1$ specimen) with predorsal abdominal vertebrae 15 (3 specimens) or 16 ( 1 specimen).

Sexual dimorphism. Though only few specimens were examined, we may report on pronounced sexual dimorphism: the pectoral fin is longer while the pectoral-pelvic distance is shorter in males and the pectoral fin reaches behind the origin of the pelvic fin (Fig. 3a, b). Also, the pectoral fin is markedly rounded with a slightly convex outer margin and the first two branched rays of about similar length forming the apex of the fin in males vs. a clearly pointed fin with a slightly concave outer margin and the first branched ray which is clearly longer than the second one forming the apex of the fin in females. The male NMW 87659:2 has prominent nuptial tuberculation: tubercles densely cover the entire dorsal and lateral head surface down to the lower margin of the interoperculum and the branchiostegal rays, anterior back along the scale margins and on the upper surface of the pectoral fin along all its rays.

Colouration (preserved). The dorsal part of the head and the body is dark grey. The flank and the abdomen are silvery. The fins are hyaline. 

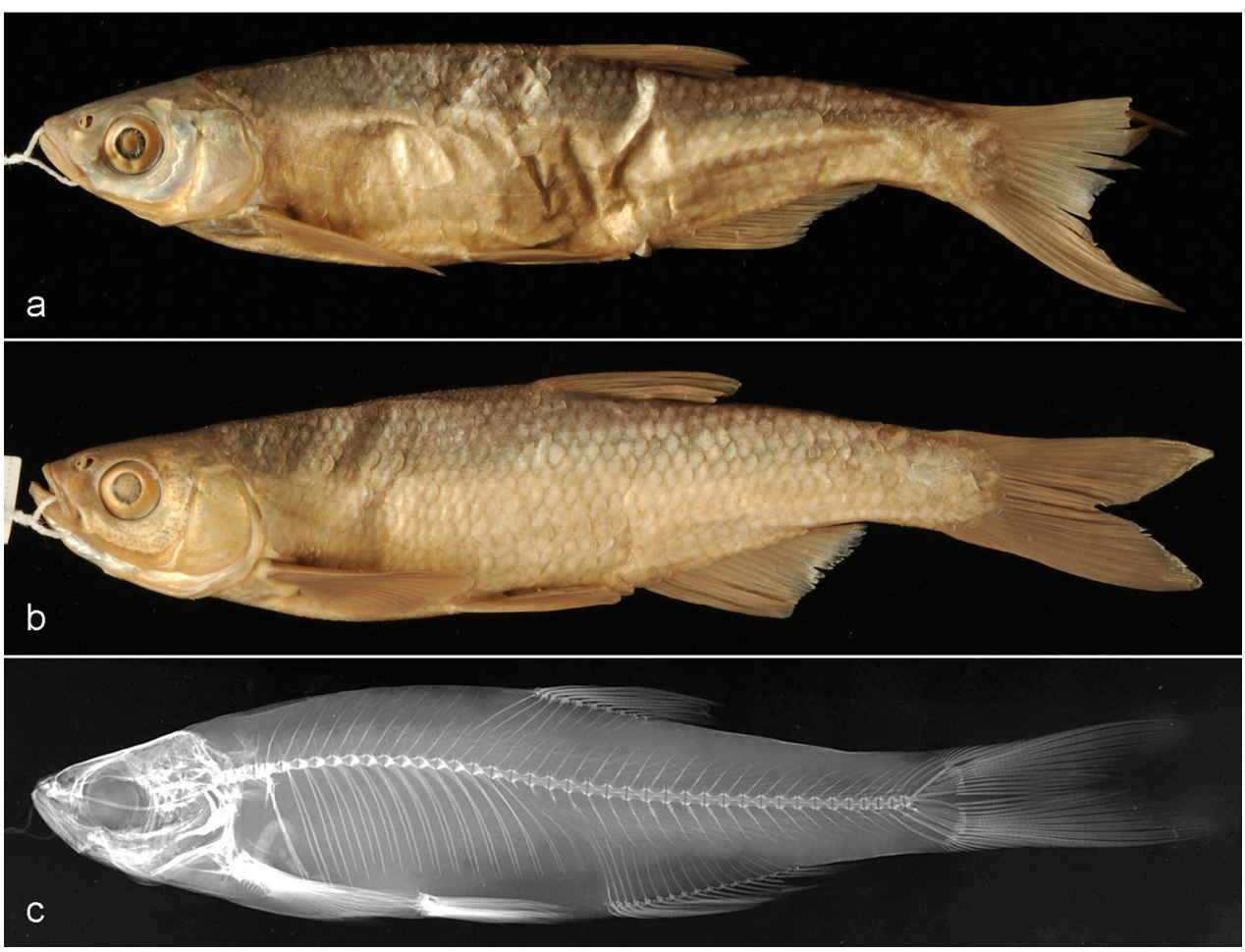

Figure 3. Alburnus scoranza, NMW 87659. a Female 106.9 mm SL b male 98.2 mm SL; NMW 87658 c radiograph, male $90.8 \mathrm{~mm}$ SL.

\section{Discussion}

As the knowledge of the biodiversity in general and of the fish fauna in particular within the Vjosa River system in Albania is very scarce (Rakaj and Flloko 1995, Shumka et al. 2018b), descriptions of fishes from this river system are commonly based on the study of Rakaj (1995). However, the Rakaj's data were mostly based on material from Prespa, Ohrid, and Skadar lakes and their tributaries. This author did not give data for specimens of the Vjosa just indicating the occurrence of a species in this river.

Recent faunal lists mentioned the occurrence of an Alburnoides Jeitteles in the Vjosa River drainage under the names either $A$. bipunctatus (Bloch, 1782) (Meulenbroek et al. 2018, Shumka 2018b) or A. prespensis (Karaman, 1928) (Shumka et al. 2018a). Morphological (Coad and Bogutskaya 2009, Bogutskaya et al. 2010) and molecular (Geiger et al. 2014, Stierandová et al. 2016) data ruled out the occurrence of $A$. bipunctatus in the Vjosa/Aoos River (Barbieri et al. 2015, 2017). Mentioning A. prespensis in the Vjosa River in Albania, Shumka et al. (2018a) just refer to previous authors, e.g., Rakaj (1995), Kottelat and Freyhof (2007), Bogutskaya et al. (2010) or Geiger et al. (2014). Whereas Rakaj (1995) and Kottelat and Freyhof (2007) do not give records of A. prespensis outside of the Prespa lakes and their tributaries, the other authors just refer to records in the Greece part (Aoos) of the Vjosa River drainage. 
Table 3. Morphometric data of Alburnus scoranza from the Vjosa River at Selenize (Albania) and Montenegro (formerly considered syntypes, see text for discussion) deposited at NMW.

\begin{tabular}{|c|c|c|c|c|c|c|}
\hline Alburnus scoranza & $\begin{array}{c}\text { NMW 55700:1 } \\
\text { female }\end{array}$ & $\begin{array}{c}55700: 2 \\
\text { female }\end{array}$ & $\begin{array}{l}87654 \\
\text { female }\end{array}$ & $\begin{array}{c}87658 \\
\text { male }\end{array}$ & $\begin{array}{c}87659: 1 \\
\text { female }\end{array}$ & $\begin{array}{c}87659: 2 \\
\text { male }\end{array}$ \\
\hline Standard length $(\mathrm{mm})$ & 125.6 & 93.4 & 70.8 & 90.8 & 106.9 & 98.2 \\
\hline \multicolumn{7}{|l|}{ Percent standard length } \\
\hline Body depth at dorsal-fin origin & 23.3 & 18.2 & 19.9 & 24.0 & 22.9 & 23.8 \\
\hline Body width at dorsal-fin origin & 10.8 & 8.7 & 8.5 & 7.8 & 8.2 & 8.5 \\
\hline Predorsal length (\% SL) & 57.8 & 57.6 & 58.4 & 54.9 & 56.0 & 54.0 \\
\hline Postdorsal length (\% SL) & 35.0 & 33.0 & 30.7 & 36.2 & 33.9 & 35.0 \\
\hline Prepelvic length (\% SL) & 47.7 & 48.9 & 45.7 & 43.6 & 47.1 & 46.1 \\
\hline Preanal length $(\% \mathrm{SL})$ & 68.5 & 69.1 & 65.0 & 64.3 & 68.2 & 66.1 \\
\hline Pectoral - pelvic-fin origin length & 24.5 & 23.6 & 23.0 & 20.9 & 23.8 & 21.1 \\
\hline Pelvic - anal-fin origin length & 21.7 & 20.8 & 19.8 & 20.1 & 21.4 & 20.0 \\
\hline Caudal peduncle length & 20.2 & 20.5 & 21.2 & 19.0 & 19.2 & 18.3 \\
\hline Caudal peduncle depth & 9.6 & 8.5 & 10.3 & 11.0 & 10.6 & 10.0 \\
\hline Caudal peduncle width & 7.0 & 5.6 & 5.7 & 5.1 & 5.5 & 5.7 \\
\hline Dorsal-fin base length & 10.5 & 11.7 & 12.2 & 11.5 & 10.8 & 12.5 \\
\hline Dorsal-fin depth & 16.4 & 18.8 & 20.5 & 20.9 & 19.6 & 21.1 \\
\hline Anal-fin base length & 14.8 & 14.0 & 16.3 & 20.0 & 16.2 & 18.9 \\
\hline Anal-fin depth & 12.7 & 15.3 & 13.4 & 14.9 & 12.4 & 15.5 \\
\hline Pectoral-fin length & 18.1 & 20.2 & 20.3 & 21.9 & 21.5 & 22.6 \\
\hline Pelvic-fin length & 13.8 & 15.9 & 14.4 & 17.6 & 15.8 & 18.3 \\
\hline Head length & 23.8 & 24.7 & 25.5 & 23.7 & 24.4 & 25.1 \\
\hline Head depth at nape & 15.1 & 15.5 & 16.9 & 15.6 & 15.7 & 17.7 \\
\hline Head width (maximum) & 11.0 & 10.5 & 11.5 & 11.3 & 11.1 & 12.5 \\
\hline Snout length & 5.3 & 6.3 & 6.6 & 6.3 & 6.9 & 7.0 \\
\hline Eye diameter (horizontal) & 6.2 & 6.7 & 7.8 & 6.7 & 6.8 & 6.8 \\
\hline Postorbital distance & 12.7 & 12.6 & 11.9 & 12.1 & 12.2 & 10.6 \\
\hline Interorbital width & 6.7 & 6.6 & 7.3 & 7.4 & 7.5 & 7.4 \\
\hline Length of upper jaw & 6.0 & 6.4 & 7.7 & 7.2 & 7.5 & 6.9 \\
\hline Length of lower jaw & 8.4 & 9.3 & 9.4 & 9.6 & 9.2 & 9.6 \\
\hline \multicolumn{7}{|l|}{ Percent head length } \\
\hline Head depth at nape & 63.3 & 62.7 & 66.1 & 65.9 & 64.2 & 70.3 \\
\hline Head width (maximum) & 46.2 & 42.3 & 44.9 & 47.6 & 45.3 & 49.7 \\
\hline Snout length & 23.3 & 25.5 & 25.9 & 26.6 & 28.2 & 27.9 \\
\hline Eye diameter (horizontal) & 25.9 & 27.0 & 30.7 & 28.3 & 28.0 & 27.2 \\
\hline Postorbital distance & 50.5 & 50.8 & 46.5 & 51.2 & 46.5 & 48.5 \\
\hline Interorbital width & 28.3 & 26.5 & 28.4 & 31.0 & 30.7 & 29.6 \\
\hline Length of upper jaw & 25.1 & 25.8 & 30.0 & 30.2 & 30.8 & 27.4 \\
\hline Length of lower jaw & 35.2 & 37.5 & 37.6 & 39.5 & 37.6 & 38.3 \\
\hline Depth of operculum & 36.9 & 37.2 & 38.2 & 37.3 & 36.5 & 37.0 \\
\hline \multicolumn{7}{|l|}{ Percent caudal peduncle length } \\
\hline Depth of caudal peduncle & 47.3 & 41.3 & 44.0 & 48.6 & 52.2 & 54.6 \\
\hline \multicolumn{7}{|l|}{ Percent interorbital distance } \\
\hline Eye diameter (horizontal) & 91.5 & 101.6 & 107.8 & 91.3 & 91.1 & 91.9 \\
\hline
\end{tabular}

Limited mitochondrial (cytb) data of Perea et al. (2010) - only one specimen from Prespa Lake and one from the Aoos were studied - showed a very close position of the two specimens. Results of Geiger et al. (2014) clearly demonstrated that the CO1 marker did not provide resolution in many groups of conventional species in the subfamily Leuciscinae (Geiger et al. 2014: table S1-C). This table lists at least 17 complexes of "closely related" leuciscine species, which include clearly morphologically distinct species, e.g., Delminichthys ghetaldii (Steindachner, 1882), D. jadovensis (Zupančič et Bogutskaya, 2002) and D. krbavensis (Zupančič \& Bogutskaya, 2002) or Squalius tenellus Heckel, 
1843 and S. microlepis Heckel, 1843. Alburnoides prespensis, A. devolli and A. fangfangae Bogutskaya, Zupančič \& Naseka, 2012 were not distinguished by COI barcode either: $A$. devolli and $A$. fangfangae from the Seman drainage were closely related to $A$. prespensis from Prespa Lake and the position of this cluster was a nearest sister to A. ohridanus (Karaman, 1928) (Skadar material was not examined) (Geiger et al. 2014). A study using a set of both nuclear (ß-actin, RAG1 and S7) and mitochondrial (cytb) markers (Stierandová et al. 2016) supported the divergence of the "prespensis+devolli+fangfangae" cluster from A. ohridanus (lineage VII) but subdivided most part of the Albanian samples into three lineages (VII, IX and X) naming them "A. prespensis species complex". This term has been in use since then (e.g., Juladeh Roudbar et al. 2016, Barbieri et al. 2017).

In the publication by Stierandová et al. (2016), the A. ohridanus lineage included the Ohrid Lake sample and some individuals from the Mat, Ishëm and Erzen Rivers Adriatic drainages south of the Ohrid-Drin-Skadar basin. The range of the A. prespensis species complex embraces Prespa Lake and five Adriatic drainages in the south of Erzen - Shkumbin, Seman, Vjosa/Aoos, Dukati, and Borshi. The internal structure of the $A$. prespensis complex based on combined data (cytb, $ß$-actin and S7) (Stierandová et al. 2016: fig. 1) cannot be interpreted from either taxonomic or zoogeographic aspects. As any morphological diagnostic characters of the voucher samples used for the genetic research have not been published, a clear taxonomic assignment of the Aoos (Greek) Alburnoides as well as of the two Albanian species from the Seman River drainage (geographically closest to the Vjosa/Aoos) is still uncertain.

Our morphological data (Table 2, Fig. 2) is not congruent with the molecular data: $A$. ohridanus is located inside the $A$. prespensis complex and the whole set of samples that belong to the latter demonstrates a high degree of morphological divergence within the group in general and between some presumptive species, in particular. However, as it can be seen from Table 3 summarising our data for samples out of the $A$. prespensis complex, they are all different in key diagnostic characters indicating a considerably high morphological diversity of the complex. Our sample is similar to samples from the Aoos in Greece (Barbieri et al. 2017) in having a poorly developed ventral keel which is commonly almost or completely scaled, and 43-49, mean 45.8, lateral-line scales to posterior margin of hypurals (45-50, mean 46.3 in Barbieri et al. (2017). However, the number of branched anal-fin rays is lower, commonly $11 \frac{1}{2}$, mean 11.2 [ $1 / 2$ ] (vs. commonly $12 \frac{1}{2} 2$, mean $11.8[1 / 2]$ in Barbieri et al. (2017).

The entire $A$. prespensis complex needs a thorough revision, especially with regard to the southern river drainages of Albania (Bogutskaya et al. 2010, Stierandová et al. 2016, Barbieri et al. 2017). The data presented in this study are a first step towards resolving the phylogenetic and taxonomic position of the Vjosa/Aoos $A$. cf. devolli populations.

The Vjosa population of $A$. scoranza in Albania was documented as Alburnus alburnus (Linnaeus, 1758) by Ahnelt and Elvira (1994). The Aoos population of $A$. scoranza in Greece was also first reported as A. alburnus by Economou et al. (2007a) and then as A. cf. scoranza (Economou et al. 2007b). Alburnus scoranza is supposedly distributed in the western Balkans from the Drin drainage, including Skadar and Ohrid lakes, south to the Aoos in Greece where it is restricted to a short section of the middle section of the river within the Konitsa plateau downstream to the Albanian border (Barbieri et al. 
2015). Based on COI barcodes, Geiger et al. (2014) showed that $A$. scoranza (material from Ohrid and Skadar lakes and the Aoos in Greece) is not included in the Adriatic Alburnus clade but is the closest neighbour to a wide group of Alburnus species spread from Portugal and France to Central Anatolia. Mangit and Yeril (2018) included some GenBank-available CO1 sequences of $A$. arborella (De Filippi, 1844), $A$. albidus (Costa, 1838), A. belvica Karaman, 1924, and A. scoranza in their analysis of mostly Turkish species and found the same pattern with $A$. scoranza as a closest sister clade to the three former species plus two from western Turkey.

While $A$. arborella occurs in northern Adriatic basin, the distribution of $A$. belvica is restricted to Prespa Lake with its tributaries (Kottelat and Freyhof 2007). Alburnus neretvae Buj, Šanda et Perea, 2010 is an endemic species of the Neretva River drainage (Buj et al. 2010) and the distribution area of $A$. scoranza comprises the basins of lakes Prespa, Ohrid, and Skadar (Kottelat and Freyhof 2007). Economou et al. (2007b) and later Geiger et al. (2014) listed this species for the Greek part of the Vjosa/Aoos River drainage. Shumka et al. (2018a) mentioned A. scoranza in a checklist for the Albanian section of the Vjosa but no exact locality data were given. Therefore, the specimens presented in this study from Selenica are the first voucher-confirmed record of $A$. scoranza for the Vjosa River system in Albania.

We could only morphologically compare our sample with the limited published data of $A$. scoranza (Buj et al. 2010; material from the Zeta, Skadar basin; Black Drin, Ohrid basin; and the Mat River, which is the geographically closest drainage south of the Drin). The Vojsa specimens have more numerous anal-fin branched rays, $14 \frac{1}{2}-15 \frac{1}{2}$ (vs. $13 \frac{1}{2}-141 / 2$ ); similar number of total lateral-line scales, $45-51$ (vs. 46-53); and, the most striking difference, gill rakers 22-25 (vs. 15-20). Interestingly, the Vojsa sample does not differ by the diagnostic counts from two specimens that had been considered syntypes of $A$. scoranza Heckel $\&$ Kner, 1857 from Skadar Lake (NMW 55700: 1 and 2) until it was supposed that the species' name was made available earlier by Bonaparte (1845) (see below). These two specimens have a sharp scaleless keel; total lateral line scales 48, 47; anal-fin branched rays 141/2; gill rakers 21, 24; vertebrae $22+19$ and $22+20$ with predorsal abdominal vertebrae 15 and 16 ; for measurements see Table 2 .

So far, clarification of the taxonomic status of $A$. scoranza from the Vjosa still needs additional morphological and genetic data, especially from the southern river basins in Albania.

Nomenclatural note on Alburnus scoranza. The most recent publications (e.g., Buj et al. 2010; Barbieri et al. 2015) follow Kottelat and Freyhof (2007: 598) in attributing the authorship to Bonaparte (1845). Bonaparte (1845: 12) lists A. scoranza (species No 122) with a reference to Heckel (no date) and the only morphological trait given in the description is the number of pharyngeal teeth (2.5-5.2). According to Art. 12.1 of the International Code of Zoological Nomenclature (the Code; International Commission on Zoological Nomenclature 1999) this indeed constitutes an available name as it is "accompanied by a description ... of the taxon that it denotes". Heckel's publication is most probably dated 1843 where Alburnus scoranza is listed (on page 1036) as a name only (authorship attributed to Heckel) with the locality as 
Montenegro, among other species names under the description of the genus Alburnus. The pharyngeal teeth 2.5-5.2 are given as a characteristic feature of the genus. This may indicate that Bonaparte only referred to these data from Heckel (1843) and did not examine any $A$. scoranza specimens himself, so, Heckel's specimens may represent the type series of the species by bibliographic reference according to Art. 72.4.1 of the Code (International Commission on Zoological Nomenclature 1999).

Heckel had apparently examined specimens of $A$. scoranza as two specimens (as Aspius scoranza Heckel, acquisition number 1843.II.18b) were registered at the NMW from "Cettinje in Montenegro" collected by himself in his 1840 travels. Unfortunately, these specimens have not been found in NMW during recent searches. Cetinje is a city (the historic old capital of Montenegro) located in the Cetinje karst field $12 \mathrm{~km}$ from Skadar Lake and even closer to the Rijeka Cernojevića River, an inflow of Skadar Lake. Heckel received two more specimens (acquisition number 1856.VII.26) described by Heckel and Kner in 1857 (page 139 footnote) much later than 1843 from Belotti (sample NMW 55700). In case a designation of neotype to fix the species name $A$. scoranza is needed in the future, the information presented above on the Heckel's specimens from Cetinje should be taken into consideration to meet the conditions of Art. 75.3 of the Code (International Commission on Zoological Nomenclature 1999).

Recent studies provide evidence that species of Alburnoides and Alburnus Rafinesque were introduced into other river systems (e.g., Simić et al. 2012, Stierandová et al. 2016, Pofuk et al. 2017, Vukić et al. 2019). As intentional and unintentional introductions of non-native fish species are common in Adriatic lake and river systems (e.g., Shumka et al. 2008, Simić et al. 2012, Piria et al. 2017, Pofuk et al. 2017, Vukić et al. 2019), historic museum collections provide important information of natural fish distributions (e.g., Palandačić et al. 2017). If several phylogenetic lineages occur in one and the same river drainage, historic museum collections may be of a crucial importance to determine native populations and apply the nomenclaturally correct name.

\section{Acknowledgements}

NB was supported by the Austrian Science Foundation (Lise Meitner Programme, project M2183-B25).

\section{References}

Ahnelt H, Elvira B (1991) Eine Kollektion von Meeres - und Süßwasserfischen der Österreichischen Adria-Tiefsee Expedition 1894. Annalen des Naturhistorischen Museums in Wien 92B: 1-13.

Barbieri R, Zogaris S, Kalogianni E, Stoumboudi MT, Chatzinikolaou Y, Giakoumi S, Kapakos Y, Kommatas D, Koutsikos N, Tachos V, Vardakas L, Economou AN (2015) Freshwater fishes and lampreys of Greece. An annotated checklist. Monographs on marine sciences 8 . Hellenic Centre for Marine Research, Athens, 129 pp. 
Barbieri R, Vukić J, Šanda R, Kapakos Y, Zogaris S (2017) Alburnoides economoui, a new species of spirlin from Central Greece and redescription of Alburnoides thessalicus (Actinopterygii: Cyprinidae). Biologia 72: 1075-1088. https://doi.org/10.1515/biolog-2017-0113

Bloch ME (1782) M. Marcus Elieser Bloch's ..., ausübenden Arztes zu Berlin, Oeconomische Naturgeschichte der Fische Deutschlands, 1. Berlin, 128 pp. https://doi.org/10.5962/bhl. title.63303

Bobori DC, Economidis P (2006) Freshwater fishes of Greece: their biodiversity, fisheries and habitats. Aquatic Ecosystems Health \& Management 9: 407-418. https://doi. org/10.1080/14634980601027855

Bogutskaya NG, Zupančič P, Naseka AM (2010) Two new species of freshwater fishes of the genus Alburnoides, A. fangfangae and A. devolli (Actinopterygii: Cyprinidae), from the Adriatic Sea basin in Albania. Proceedings of the Zoological Institute RAS 314: 448-486

Bonaparte CL (1845) Catalogo metodico dei ciprinidi d'Europa, e rilievi sul volume XVII dell' istoria naturale dei pesci del sig. Valenciennes. Pirola, Milano, 20 pp. https://doi. org/10.5962/bhl.title.5781

Buj I, Vukić J, Šanda R, Perea S, Ćaleta M, Marčić Z, Bogut I, Povz M, Mrakovčić M (2010) Morphological comparison of bleaks (Alburnus, Cyprinidae) from the Adriatic Basin with description of a new species. Folia Zoologica 59: 129-141. https://doi.org/10.25225/fozo. v59.i2.a8.2010

Costa OG [1838] (1829-1853) Fauna del regno di Napoli, ossia enumerazione di tutti gli animali che abitano le diverse regioni di questo regno e le acque che le bagnano, etc. Pesci. Fauna del regno di Napoli Part 1. Azzolino, Napoli, 511 pp. https://doi.org/10.5962/bhl. title. 135337

De Filippi F (1844) Pesci finora osservati in Lombardia. Notizie naturali e civili su la Lombardia 1: 389-406.

Durand DJ, Templeton AR, Guinand B, Imsiridou A, Bouvet Y (1999) nested clade and phylogeographic analyses of the Chub, Leiuciscus cephalus (Teleostei, Cyprinidae), in Greece: Implications for Balkan Peninsula biogeography. Molecular Phylogenetics and Evolution 13: 566-580. https://doi.org/10.1006/mpev.1999.0671

Economidis PS (1989) distribution pattern of the genus Barbus (Pisces, Cyprinidae) in the freshwaters of Greece. Travaux du Muséum National d'Histoire Naturelle"Grigore Antipa" 30: 223-229.

Economidis PS, Bănărescu PM (1991) The Distribution and origins of freshwater fishes in the Balkan Peninsula, especially in Greece. Internationale Revue der Gesamten Hydrobiologie und Hydrographie 76(2): 257-284. https://doi.org/10.10.1002/iroh.19910760209

Economou AN, Zogaris S, Chatzinikolaou Y, Tachos V, Giakoumi S, Kommatas D, Koutsikos N, Vardakas L, Blasel K, Dussling U (2007a) Development of an ichthyological multimetric index for ecological status assessment of Greek mountain streams and rivers. Hellenic Center for Marine Research - Institute of Inland Waters / Hellenic Ministry for Development. Technical Report, Athens, 166 pp. [in Greek]

Economou AN, Giakoumi S, Vardakas L, Barbieri R, Stoumboudi M, Zogaris S (2007b) The freshwater ichthyofauna of Greece - an update based on a hydrographic basin survey. Mediterranean Marine Science 8: 91-168. https://doi.org/10.12681/mms.164 
Geiger MF, Herder F, Monaghan MT, Almada V, Barbieri M, Bariche M, Berrebi P, Bohlen J, Casal-Lopez M, Delmastro GB, Denys GPJ, Dettai A, Doadrio I, Kalogianni E, Kärst H, Kottelat M, Kovačić M, Laporte M, Lorenzoni M, Marčić Z, Özulug M, Perdices A, Perea S, Persat H, Porcelotti S, Puzzi C, Robalo J, Šanda R, Schneider M, Šlechtová V, Stoumboudi M, Walter S, Freyhof J (2014) Spatial heterogeneity in the Mediterranean biodiversity hotspot affects barcoding accuracy of its freshwater fishes. Molecular Ecology Resources 14: 1210-1221. https://doi.org/10.1111/1755-0998.12257.

Graf W, Bauerfeind E, Bequiari S, Duda M, Frank T, Gunczy J, Heckes U, Hess M, Kunz G, Meulebroek P, Paill W, Rabitsch W, Vitecek S (2017) The fauna of the Vjosa River and the adjacent floodplain at Poçem. University of Vienna, Vienna. http://>balkan-rivers.net/ sites/default/files/Vjosa_assessment_201709.pdf [accessed 19 April 2019]

Heckel JJ (1843) Abbildungen und Beschreibungen der Fische Syriens, nebst einer neuen Classification und Characteristik sämmtlicher Gattungen der Cyprinen. In: Fenzl E, Heckel JJ, Redtenbacher L (Eds) Abbildungen und Beschreibungen neuer und seltener Thiere und Pflanzen in Syrien und im westlichen Taurus gesammelt von Th. Kotschy. V. 1 (pt 2). E. Schweizerbart'sche Verlagshandlung, Stuttgart, 991-1044. https://doi.org/10.5962/bhl. title. 14055

Heckel JJ, Kner R (1857) Die Süsswasserfische der Österreichischen Monarchie, mit Rücksicht auf die angränzenden Länder. Wilhelm Egelmann, Leipzig, 388 pp. https://doi. org/10.5962/bhl.title.8197

International Commission on Zoological Nomenclature (1999) International Code of Zoological Nomenclature. $4^{\text {th }}$ Ed. International Trust for Zoological Nomenclature, London, 106 pp.

Juladeh Roudbar A, Eagderi S, Esmaili HR, Coad BW, Bogutskaya N (2016) A molecular approach to the genus Alburnoides using COI sequences data set and the description of a new species, $A$. damghani, from the Damghan River system (the Dashet-e Kavir Basin, Iran) (Actinopterygii, Cyprinidae). ZooKeys 579: 157-181. https://doi.org/10.3897/ zookeys.579.7665

Karaman S (1924) Pisces Macedoniae. Hrvatska Stamparija, Split, 90 pp.

Karaman S (1928) Beiträge zur Ichthyologie von Jugoslavien I. Glasnik Skopskog Naucnog Drustva [Bulletin de la Société Scientifique de Skopje] 6: 147-176.

Kottelat M, Freyhof J (2007) Handbook of European freshwater fishes. Kottelat, Cornol, Switzerland and Freyhof, Berlin, 646 pp.

Linnaeus C (1758) Systema Naturae, Ed. X. (Systema naturae per regna tria naturae, secundum classes, ordines, genera, species, cum characteribus, differentiis, synonymis, locis). Tomus I. Editio decima, reformata, v. 1. Holmiae: 824 pp. https://doi.org/10.5962/bhl.title.542

Mangit F, Yeril SV (2018) Systematic evaluation of the genus Alburnus (Cyprinidae) with description of a new species. Hydrobiologia 807: 297-312. [Published online: 12 October 2017] https://doi.org/10.1007/s10750-017-3405-y

Marková S, Šanda R, Crivelli A, Shumka S, Wilson IF, Vukić J, Berrebi P, Kotlík P (2010) Nuclear and mitochondrial DNA sequence data reveal the evolutionary history of Barbus(Cyprinidae) in the ancient lake systems of the Balkans. Molecular Phylogenetics and Evolution 55(2): 488-500. https://doi.org/10.1016/j.ympev.2010.01.030 
Meulenbroek P, Shumka S, Schiemer F (2018) First reconnaissance of habitat partitioning and fish diversity in the alluvial zone of the river Vjosa, Albania. Acta ZooBot Austria 155: 177-186.

Palandačić A, Naseka A, Ramler D, Ahnelt H (2017) Contrasting morphology with molecular data: an approach to revision of species complexes based on the example of European Phoxinus (Cyprinidae). BMC Evolutionary Biology 17: 184. Https://doi.org/10.1186/ s12862-017-1032-x

Perea S, Böhme M, Zupančič P, Freyhof J, Šanda R, Özulug M, Abdoli A, Doadrio I (2010) Phylogenetic relationships and biogeographical patterns in Circum-Mediterranean subfamily Leuciscinae (Teleostei, Cyprinidae) inferred from both mitochondrial and nuclear data. BMC Evolutionary Biology 10: 265. https://doi.org/10.1186/1471-2148-10-265.

Piria M, Simonović P, Kalogianni E, Vardakas L, Koutsikos N, Zanella D, Ristovska M, Apostolou A, Adrović A, Mrdak D, Tarkan AS, Milošević D, Zanella LN, Bakui R, Ekmekçi FG, Povz M, Korro K, Nikolić V, Škrijelj R, Kostov V, Gregori A, Joy M (2017) Alien freshwater fish species in the Balkans-Vectors and pathways of introduction. Fish and Fisheries 2017: 1-32. https://doi.org/10.1111/faf.12242

Pofuk M, Zanella D, Piria M (2017) An overview of the translocated native and non-native fish species in Croatia: pathways, impacts and management. Management of Biological Invasions 8: 42-435. Https://doi.org/10.3391/mbi.2017.8.3.16

Rakaj N (1995) Ichthyofauna of Albania. University of Tirana, Tirana, 700 pp. [In Albanian]

Rakaj N, Flloko A (1995) Conservation status of freshwater fish of Albania. Biological Conservation 72: 195-199. https://doi.org/10.1016/0006-3207(94)00082-2

Shumka S, Meulenbroek P, Schiemer F, Šanda R (2018a) Fishes of River Vjosa - an annotated checklist. Acta ZooBot Austria 155: 163-176.

Shumka S, Bego F, Beqiraj S, Paparisto A, Kashta L, Miho A, Nika O, Marka J, Shuka L (2018b) The Vjosa catchment - a natural heritage. Acta ZooBot Austria 155: 349-376.

Shumka S, Paparisto A, Grazhdani S (2008) Identification of non-native freshwater fishes in Albania and assesement of their potential threats to the national biological freshwater diversity. Proceedings Balwois Conference, Ohrid, Macedonia 040: 1-6.

Simić V, Simić S, Paunović M, Radojković P, Petrović A (2012) Scardinius knezevici Bianco \& Kottelat, 2005 and Alburnus scoranza Bonaparte, 1845: New species of ichthyofauna of Serbia and the Danube Basin. Archives of Biological Sciences, Belgrade 64: 981-990. https://doi.org/10.2298/ABS1203981S

Steindachner F (1882) Beiträge zur Kenntniss der Fische Afrika’s (II.) und Beschreibung einer neuen Paraphoxinus-Art aus der Herzegowina. Denkschriften der Kaiserlichen Akademie der Wissenschaften in Wien, Mathematisch-Naturwissenschaftliche Classe 45(1): 1-18. https://doi.org/10.5962/bhl.title.69322

Stierandová S, Vukić J, Vasil'eva ED, Zogaris S, Shumka S, Halačka L, Švátora M, Nowak M, Stefanov T, Koščo J, Mendel J (2016) A multilocus assessment of nuclear and mitochondrial sequence data elucidates phylogenetic relationships among European spirlins (Alburnoides, Cyprinidae). Molecular Phylogenetics and Evolution 94: 479-491. https:// doi.org/10.1016/j.ympev.2015.10.025 [E-published 2015 Nov 3] 
Šanda R, Vukić J, Choleva L, Kř́žek J, Šedivá A, Shumka S, Wilson IF (2008) Distribution of loach fishes (Cobitidae, Nemacheilidae) in Albania, with genetic analysis of populations of Cobitis ohridana. Folia Zoologica 57: 42-50.

Vukić J, Eliášová K, Marić D, Šanda R (2019) Occurrence of alien spirlin (Alburnoides sp.) in the Neretva river basin. Knowledge and Management of Aquatic Ecosystems 420: 15. https://doi.org/10.1051/kmae/2019007

Zogaris S, Economou AN (2017) The biogeographic characteristics of the river basins in Greece. In: Skoulikidis NT, Dimitriou E, Karaouzas I (Eds) The Rivers of Greece: Evolution, current status and perspectives. 93-95. http://doi.org/10.1007/698_2017_475

Zupančič P, Bogutskaya N (2002) Description of two new species, Phoxinellus krbavensis and $P$. jadovensis, re-description of $P$. fontinalis Karaman, 1972, and discussion of the distribution of Phoxinellus species (Teleostei: Cyprinidae) in Croatia and in Bosnia and Herzegovina. Natura Croatica 11(4): 411-437. 